\title{
PENGARUH CAPITAL ADEQUACY RATIO DAN LOAN TO DEPOSIT RATIO TERHADAP EARNING BEFORE TAX PADA PT. BANK BJB (PERSERO), TBK PERIODE 2012-2018
}

\author{
1 *Slamet Wahyuni, ${ }^{2}$ Padila Muchtar \\ 1STIE Hidayatullah, Depok, Jawa Barat, Indonesia \\ 2Institut Agama Islam Negeri (IAIN) Palopo \\ *slamet.wahyudi@stiehidayatullah.ac.id
}

\begin{abstract}
Abstrak
Penelitian ini bertujuan untuk mengetahui Pengaruh Capital Adequacy Ratio dan Loan to Deposit Ratio Terhadap Earning Before Tax Pada PT. Bank BJB (Persero), Tbk. Metode yang digunakan adalah explanatory research. Teknik analisis menggunakan analisis statistik dengan pengujian regresi, korelasi, determinasi dan uji hipotesis. Hasil penelitian ini Capital Adequacy Ratio berpengaruh negatif signifikan terhadap Earning Before Tax sebesar 5,1\%, uji hipotesis diperoleh thitung $<\mathrm{t}$ tabel atau $(-0,520<2,571)$. Loan to Deposit Ratio berpengaruh negatif signifikan terhadap Earning Before Tax sebesar 12,4\%, uji hipotesis diperoleh t hitung $<\mathrm{t}$ tabel atau $-0,841<2,571$ ). Capital Adequacy Ratio dan Loan to Deposit Ratio secara simultan berpengaruh negatif namun tidak signifikan terhadap Earning Before Tax diperoleh persamaan regresi $Y=176,283-4,730 X 1-0,132 X 2$ dan nilai determinasi sebesar 49,6\%, uji hipotesis diperoleh nilai $\mathrm{F}$ hitung $<\mathrm{F}$ tabel atau $(1,970<5,410)$.
\end{abstract}

Kata Kunci: Capital Adequacy Ratio, Loan to Deposit Ratio, Earning Before Tax.

\begin{abstract}
This study aims to determine the effect of the Capital Adequacy Ratio and the Loan to Deposit Ratio on Earning Before Tax at PT. Bank BJB (Persero), Tbk. The method used is explanatory research. The analysis technique uses statistical analysis with regression testing, correlation, determination and hypothesis testing. The results of this study Capital Adequacy Ratio has a significant negative effect on Earning Before Tax by 5.1\%, the hypothesis test is obtained t count $<t$ table or $(-0.520<2.571)$. Loan to Deposit Ratio has a significant negative effect on Earning Before Tax by $12.4 \%$, the hypothesis test is obtained t count $<t$ table or $-0.841<2.571$ ). Capital Adequacy Ratio and Loan to Deposit Ratio simultaneously have a negative but insignificant effect on Earning Before Tax, the regression equation $Y=176,283-4,730 X 1-0,132 X 2$ and a determination value of $49.6 \%$, hypothesis testing obtained $F$ value $<F$ table or $(1,970<5,410)$.
\end{abstract}

Keywords: Capital Adequacy Ratio, Loan to Deposit Ratio, Earning Before Tax.

\section{PENDAHULUAN}

Bank adalah suatu lembaga keuangan yang usaha pokoknya adalah menghimpun dana dan menyalurkan dana tersebut ke masyarakat dalam bentuk pinjaman serta memberikan jasa-jasa. Bank dalam beroprasi lebih banyak menggunakan dana dari masyarakat dibanding dengan modal sendiri dari pemilik atau pemegang saham. Kepercayaan masyarakat terhadap perbankan sesungguhnya sangat dipengaruhi oleh kinerja yang dicapai oleh perbankan itu sendiri dengan memelihara kesehatan bank dan bagaimana upaya manajemen perbankan mengantisipasi setiap perubahan yang terjadi dilingkungan baik nasional maupun global. Kestabilan lembaga perbankan sangat dibutuhkan dalam suatu perekonomian. Kestabilan ini tidak saja dilihat dari jumlah uang beredar, namun juga dilihat dari jumlah bank yang ada sebagai perangkat penyelenggaraan keuangan.

PT Bank BJB (Persero), Tbk merupakan bank yang bermetamorfosa dari BPD menjadi bank go public pada tanggal 16 April 1999, Nama PT. Bank BJB (Persero) Tbk. itu sendiri mempunyai makna yaitu sebuah akronim menggambarkan sifat kesederhanaan serta sifat modern masyarakat, nama tersebut menggambarkan transformasi menjadi lebih aktif dan profesional dalam melayani semua lapisan masyarakat diseluruh indonesia. Dalam bentuk sayap pada logonya mempunyai arti menjangkau jauh dalam memberikan pelayanan terbaik melambangkan tekad serta upaya untuk memberikan yang terbaik kepada nasabah. PT Bank BJB (Persero), Tbk. merupakan 
cerminan bagi perbankan Indonesia dari bank daerah menjadi bank nasional dan bisa bersaing di dunia perbankan dengan target masuk 12 besar di tahun 2016 sementara di tahun 2015 baru masuk 14 nasional. (Heryawan: 2015).

Sehat tidaknya kinerja keungan perbankan dapat dilihat memalui kinerja profitabilitasnya suatu bank tersebut. Tingkat kesehatan bank dapat dinilai dari beberapa indikator yang dijadikan dasar penilaian adalah laporan keuangan bank tersebut. Berdasarkan laporan itu akan dapat dihitung sejumlah rasio keungan yang lazim dijadikan dasar penilaian tingkat kesehatan bank.

Analisis rasio keuangan memungkinkan pihak manajemen untuk mengidentifikasi perubahan-perubahan pokok pada trend jumlah, dan hubungan serta alasan perubahan tersebut. Hasil analisis laporan keuanagan akan membantu menginterpretasikan berbagai hubungan kunci serta kecenderungan yang dapat memberikan dasar pertimbanagan mengenai potensi keberhasilan perusahaan diperiode mendatang.

Informasi laporan keuangan ini akan lebih bermanfaat jika terdapat proses penguraian pos-pos laporan keungan menjadi unti informasi yang lebih kecil dan melihat hubungan yang bersifat signifikan sehingga mempunyai makna, baik secara kuantitaf maupun kualitatif. Proses penguraian tersebut dinamakan analisis laporan keuangan. Meskipun laporan keuangan hanya menggambarkan pengaruh keuangan dari periode lalu, peranannya tetap sangat penting dalam proses pengambilan keputusan yang berdampak terhadap perusahaan periode yang akan datang. Hal ini sangat sesuai dengan penyajian laporan keuangan yaitu, menyediakan informasi yang sangat menyangkut posisi keuangan,kinerja serta perubahan posisi keuangan suatu perusahaan yang bermanfaat bagi sejumlah besar pemakai dalam pengambilan keputusan ekonomi.

Disebutkan pula bahwa pihak-pihak yang berkepentingan dengan laporan keuangan adalah investor yang telah menanamkan modalnya sekarang dan investor potensial, karyawan pemberi pinjaman (kreditur), pemasok dan kreditur usaha lainnya, pelanggan, pemerintah serta lembaga- lembaga dan masyarakat. Laporan keuangan yang disajikan untuk memenuhi beberapa kebutuhan informasi yang berbeda. Salah satu informasi penting dalam keuangan adalah informasi mengenai laba. Informasi ini sangat penting karena laba menjelaskan bagaimana kinerja perusahaan selama satu periode diperiode lalu. Kinerja keuangan bank dapat dinilai dari rasio kesuangan bank seperti, Pengaruh Capital Edequacy Ratio (CAR) dan Loan to Deposite Ratio (LDR) terhadap Earning Before Tax (EBT).

Berikut saya tampilkan Data Keuangan PT. Bank BJB (Persero), Tbk. Periode 20122018.

Tabel 1: Data Keuangan CAR, LDR, dan EBT

\begin{tabular}{|c|c|c|c|}
\hline Tahun & Capital Adequacy Ratio (\%) & Loan to Deposite Ratio (\%) & Earning Before Tax (\%) \\
\hline 2012 & 18,11 & 74,09 & 41,38 \\
\hline 2013 & 16,51 & 96,47 & 36,65 \\
\hline 2014 & 16,08 & 93,18 & 31,94 \\
\hline 2015 & 16,21 & 88,13 & 35,44 \\
\hline 2016 & 18,43 & 86,72 & 24,08 \\
\hline 2017 & 17,55 & 87,54 & 35,65 \\
\hline 2018 & 16,76 & 86,88 & 37,75 \\
\hline Rata-rata & 17,09 & 87,57 & 34,70 \\
\hline
\end{tabular}

CAR digunakan untuk mengukur kecukupan modal yang dimiliki bank untuk menjujung aktiva yang mengandung atau menghasilkan risiko, misalnya kredit yang diberikan. Besarnya CAR diukur melalui rasio antara modal sendiri terhadap Aktiva Tertimbang Akibat Risiko (ATMR). Dari periode tahun 2012-2018 diperoleh nilai CAR yang fluktuatif dengan rata-rata pertahun sebesar 17,09\%. Gubernur Bank Indonesia secara resmi mengumumkan Implementasi Arsitekstur Perbankan Indonesia (API) yang merupakan suatu bluprint mengenai arah dan tatanan perbankan nasional kedepan. Salah satu program API adalah mempersyaratkan modal minimum bagi bank 
umum (termasuk BPD) menjadi 100 milyar dengan CAR minimum $8 \%$ selambatlambatnya tahun 2010. Semakin tinggi CAR maka semakin kuat kemampuan bank tersebut untuk menanggung risiko dari setiap kredit atau aktiva produktif yang beresiko. Jika nilai CAR tinggi (sesuai dengan ketentuan Bank Indonesia sebesar 8\%) berarti bahwa bank tersebut mampu membiayai operasi bank, keadaan yang menguntungkan tersebut dapat memberikan konstribusi yang cukup besar bagi profitabilitas bank (ROA) yang bersangkutan. Dari data diatas dapat dilihat bahwa CAR pada PT Bank BJB Tbk. mengalami fluktuasi selama 5 tahun terakhir.

Rasio LDR digunakan untuk mengukur tingkat kemampuan bank tersebut dalam hal ini Bank BJB membayar hutang-hutangnya dan membayar kembali kepada deposannya. Dari periode tahun 2012-2018 diperoleh nilai LDR yang fluktuatif dengan rata-rata pertahun sebesar 87,57\%. Nilai LDR dapat memenuhi permintaan kredit yang diajukan. LDR adalah rasio antara seluruh jumlah kredit yang diberikan terhadap dana pihak ketiga. Besarnya jumlah kredit yang disalurkan akan menetukan keuntungan bank. Jika bank tidak mampu menyalurkan kredit sementara dana yang terhimpun banyak maka akan menyebabkan bank tersebut rugi. Semakin tinggi LDR, laba bank semakin meningkat (dengan asumsi bank tersebut mampu menyalurkan kreditnya dengan efektif). Dengan meningkatnya laba bank, kinerja bank juga meningkat. Dengan demikian, besar kecilnya rasio LDR suatu bank akan mempengaruhi kinerja bank tersebut. Pada tabel diatas menunjukan tingkat rasio LDR setiap tahun mengalami fluktuasi dan beberapa tahun tertentu mengalami tingkat kesehatan yang bermasalah yaitu batas sehat LDR menurut Bank Indonesia adalah 78\% - 92\%.

Ukuran Earning yang digunakan adalah Earning Before Tax (EBT) pada industri perbankan. Earning Before Tax (EBT) adalah laba bersih yang belum dikurangi dengan beban atau biaya pajak. EBT dapat juga didifinisikan sebagai uang yang disimpan oleh perusahaan sebelum dikuranggi karena harus membayar pajak. EBT mengkuantifikasi keuntungan opeasional dan non-operasional perusahaan sebelum pajak diperhitungkan, selain itu, indikator kinerja ini menunjukan ukuran untuk membandingkan perusahaan di yurisdiksi pajak yang berbeda. Signifikansi EBT yaitu memiliki signikasi besar bagi para analisis investasi karena menyediakan info berguna yang diperlukan untuk mengevaluasi kinerja operasional badan usaha tanpa mempertimbangkan implikasi pajak. Dengan menghapus faktor pajak, EBT sangat membantu meminimalkan variabel yang mungkin berbeda di berbagai perusahaan, sehingga fokus analisis pada profitabilitas operasi sebagai kuantifikasi dari kinerja. Berdasarkan alasan tersebut EBT dijadikan indikator dari profitabilitas dalam penelitian ini. Berdasarkan data diatas maka bisa dilihat bahwa EBT pada PT. Bank BJB (Persero), Tbk. mengalami fluktuasi dalam 7 tahun terakhir dengan rata-rata pertahun sebesar 34,70\%.

Berdasarkan latar belakang tersebut maka penulis mengajukan penelitian yang berjudul "Pengaruh Capital Edequacy Ratio (CAR) dan Loan to Deposit Ratio (LDR) terhadap Earning Before Tax (EBT) pada PT Bank BJB (Persero), Tbk. Periode 20122018".

\section{TINJAUAN PUSTAKA}

\section{Capital Adequacy Ratio}

Capital Edequacy Ratio (CAR) Menurut Darmawi (2011:91), salah satu komponen faktor permodalan adalah kecukupan modal. Rasio untuk menguji kecukupan modal bank yaitu rasio Capital Adequacy Ratio (CAR). Capital Adequacy Ratio (CAR) juga biasa disebut sebagai rasio kecukupan modal, yang berarti jumlah modal sendiri yang diperlukan untuk menutup risiko kerugian yang timbul dari penanaman aktiva- aktiva yang mengandung risiko serta membiayai seluruh benda tetap dan inventaris bank.

\section{Loan to Deposit Ratio}

Loan Deposit Rasio (LDR). Menurut Simorangkir (2006:147), Loan to Deposit Ratio dinyatakan sebagai "Loan to Deposit Ratio merupakan perbandingan antara kredit yang diberikan dengan dana pihak ketiga, termasuk pinjaman yang diterima, tidak termasuk pinjaman subordinasi.

\section{Earning Before Tax}

Earning Before Tax (EBT). Menurut Wild, Subramanyam, dan Halsey (2005:25) 
Earning Before Tax merupakan "laba dari operasi berjalan sebelum cadangan untuk pajak penghasilan".

\section{METODE}

Populasi dalam penelitian ini berdasar laporan keuangan selama 7 tahun PT. Bank BJB (Persero), Tbk. Teknik pengambilan sampling dalam penelitian ini adalah samplel jenuh, dimana semua anggota populasi dijadikan sebagai sampel. Dengan demikian sampel dalam penelitian ini laporan keuangan selama 7 tahun. Jenis penelitian yang dipakai adalah asosiatif, dimana tujuannya adalah untuk mengetahui mencari keterhubungan antar variabel independen terhadap variabel dependen. Dalam menganalisis data digunakan uji asumsi klasik, regresi, koefisien korelasi, koefisien determinasi dan uji hipotesis baik parsial maupun simultan.

\section{HASIL DAN PEMBAHASAN}

\section{Analisis Deskriptif}

Pada pengujian ini digunakan untuk mengetahui besarnya persentase minimum dan maksimum, persentase rata-rata dan standar deviasi dari masingmasing variabel. Adapun hasilnya sebagai berikut:

Tabel 2. Hasil Analisis Descriptive Statistics

Descriptive Statistics

N Minimum Maximum Mean Std. Deviation

\begin{tabular}{|l|l|l|l|l|r|r|}
\hline$C A R(X 1)$ & 7 & 16.08 & 18.43 & 17.0929 & .93874 \\
\hline$L D R(X 2)$ & 7 & 74.09 & 96.47 & 87.5729 & 6.99888 \\
\hline$E B T(Y)$ & 7 & 24.08 & 41.38 & 34.6986 & 5.47082 \\
\hline Valid N (listwise) & 7 & & & & \\
\hline
\end{tabular}

Capital Adequacy Ratio diperoleh nilai minimum sebesar $16,08 \%$ dan nilai maximum 18,43\% dengan rata-rata sebesar 17,09\% dengan standar deviasi $0,938 \%$.

Loan to Deposit Ratio diperoleh nilai minimum sebesar $74,09 \%$ dan nilai maximum $96,47 \%$ dengan nilai rata-rata sebesar $87,57 \%$ dengan standar deviasi $6,99 \%$.

Earning Before Tax diperoleh nilai minimum sebesar $24,08 \%$ dan nilai maximum $41,38 \%$ dengan rata-rata sebesar 34,69 dengan standar deviasi $5,47 \%$.

\section{Analisis Verifikatif}

Pada analisis ini dimaksudkan untuk mengetahui pengaruh variabel independen terhadap variabel dependen. Adapun hasil pengujian sebagai berikut:

\section{a. Analisis Regresi Linier Berganda}

Uji regresi ini dimaksudkan untuk mengetahui perubahan variabel dependen jika variabel independen mengalami perubahan. Adapun hasil pengujiannya sebagai berikut:

Tabel 3. Hasil Pengujian Regresi Liner Berganda Coefficients ${ }^{\mathrm{a}}$

\begin{tabular}{|c|c|c|c|c|c|}
\hline & \multicolumn{2}{|c|}{ Unstandardized Coefficients } & Standardized Coefficients & & \\
\hline Model & $\mathrm{B}$ & Std. Error & Beta & $\mathrm{t}$ & Sig. \\
\hline 1 (Constant) & 176.283 & 72.551 & & 2.430 & .072 \\
\hline CAR (X1) & -4.730 & 2.751 & -.812 & -1.719 & .161 \\
\hline$L D R(X 2)$ & -.132 & .206 & -.328 & -.641 & .545 \\
\hline
\end{tabular}

a. Dependent Variable: EBT (Y)

Berdasarkan hasil pengujian pada tabel di atas, diperoleh persamaan regresi $\mathrm{Y}=176,283-4,730 \mathrm{X} 1$ 0,132X2. Dari persamaan tersebut dijelaskan sebagai berikut:

1) Konstanta sebesar 176,283 diartikan jika Capital Adequacy Ratio dan Loan to Deposit Ratio tidak ada, maka telah terdapat nilai Earning Before Tax sebesar 176,283 point.

2) Koefisien regresi Capital Adequacy Ratio sebesar -4,730, angka ini negatif artinya setiap ada peningkatan Capital Adequacy Ratio sebesar -4,730 maka Earning Before 
Tax akan mengalami penurunan sebesar $-4,730$ point.

3) Koefisien regresi Loan to Deposit Ratio sebesar -0,132, angka ini negatif artinya setiap ada peningkatan Loan to Deposit Ratio sebesar -0,132 maka Earning Before Tax akan mengalami penurunan sebesar $-0,132$ point.

\section{b. Analisis Koefisien Korelasi}

Analisis koefisien korelasi dimaksudkan untuk mengetahui tingkt kekuatan hubungan dari variabel independen terhadap variabel dependen baik secara parsial maupun simultan. Adapun hasil pengujian sebagai berikut:

Tabel 4. Hasil Pengujian Koefisien Korelasi Capital Adequacy Ratio Terhadap Earning

Before Tax

Correlations $^{\mathrm{b}}$

\begin{tabular}{llr|r} 
& & & \\
\hline CAR (X1) & Pearson Correlation & 1 & EBT (Y) \\
\cline { 2 - 4 } & Sig. (2-tailed) & & -.227 \\
\hline \multirow{2}{*}{ EBT (Y) } & Pearson Correlation & -.227 & .625 \\
\cline { 2 - 4 } & Sig. (2-tailed) & .625 & \\
\hline
\end{tabular}

Berdasarkan hasil pengujian diperoleh nilai korelasi sebesar $-0,227$ artinya Capital Adequacy Ratio memiliki hubungan yang negatif lemah terhadap Earning Before Tax.

Tabel 5. Hasil Pengujian Koefisien Korelasi Loan to Deposit Ratio Terhadap Earning Before Tax

\section{Correlations $^{\mathrm{b}}$}

\begin{tabular}{llr|r} 
& & $L D R(X 2)$ & $E B T(Y)$ \\
\hline \multirow{2}{L}{ LDR (X2) } & Pearson Correlation & 1 & -.352 \\
\cline { 2 - 4 } & Sig. (2-tailed) & & .439 \\
\hline \multirow{2}{*}{ BDT $(Y)$} & Pearson Correlation & -.352 & 1 \\
\cline { 2 - 4 } & Sig. (2-tailed) & .439 & \\
\hline
\end{tabular}

Berdasarkan hasil pengujian diperoleh nilai korelasi sebesar $-0,352$ artinya Loan to Deposit Ratio memiliki hubungan yang negatif sedang Tabel 6. Hasil Pengujian Koefisien Korelasi Capital Adequacy Ratio dan Loan to Deposit Ratio secara simultan Terhadap Earning Before Tax

Model Summary

\begin{tabular}{ll|l|l|l|} 
Model & R & R Square & Adjusted R Square & Std. Error of the Estimate \\
\hline 1 &
\end{tabular}

\begin{tabular}{lrrrr}
\hline 1 & $.704^{\mathrm{a}}$ & .496 & .244 & 4.75591 \\
\hline a. Predictors: (Constant), LDR (X2), CAR (X1)
\end{tabular}

Berdasarkan hasil pengujian diperoleh nilai korelasi sebesar 0,760 artinya Capital Adequacy Ratio dan Loan to Deposit Ratio secara simultan memiliki hubungan yang kuat terhadap Earning Before Tax.

\section{c. Analisis Koefisien Determinasi}

Analisis koefisien determinasi dimaksudkan untuk mengetahui besarnya persentase pengaruh dari variabel independen terhadap variabel dependen baik secara parsial maupun simultan. Adapun hasil pengujian sebagai berikut:

Tabel 7. Hasil Pengujian Koefisien Determinasi Capital Adequacy Ratio Terhadap Earning

Before Tax

Model Summary

\begin{tabular}{ll|l|l|l} 
Model & R & R Square & Adjusted R Square & Std. Error of the Estimate \\
\hline 1
\end{tabular}

\begin{tabular}{lrrrr}
\hline 1 & $.227^{\mathrm{a}}$ & .051 & -.138 & 5.83715 \\
\hline a. Predictors: (Constant), CAR (X1) & &
\end{tabular}


Berdasarkan hasil pengujian diperoleh nilai determinasi sebesar 0,051 artinya Capital Adequacy Ratio

Tabel 8. Hasil Pengujian Koefisien Determinasi Loan to Deposit Ratio Terhadap Earning Before Tax

\section{Model Summary}

\begin{tabular}{cc|c|c|c} 
Model & $\mathrm{R}$ & $\mathrm{R}$ Square & Adjusted R Square & Std. Error of the Estimate \\
\hline 1 &
\end{tabular}

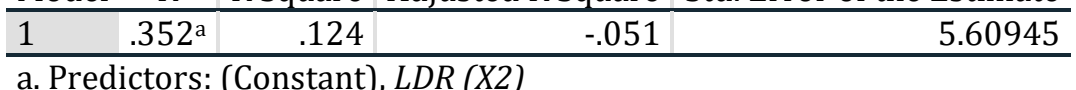

Berdasarkan hasil pengujian diperoleh nilai determinasi sebesar 0,124 artinya Loan to Deposit Ratio

Tabel 9. Hasil Pengujian Koefisien Determinasi Capital Adequacy Ratio dan Loan to Deposit Ratio Terhadap Earning Before Tax

Model Summary

\begin{tabular}{lr|r|r|r} 
Model & $\mathrm{R}$ & $\mathrm{R}$ Square & Adjusted R Square & Std. Error of the Estimate \\
\hline 1 & $.704^{\mathrm{a}}$ & .496 & .244 & 4.75591 \\
\hline a. Predictors: (Constant), $\operatorname{LDR}(X 2)$, CAR $(X 1)$
\end{tabular}

Berdasarkan hasil pengujian diperoleh nilai determinasi sebesar 0,496 artinya Capital Adequacy Ratio dan Loan to Deposit Ratio secara simultan memiliki kontribusi pengaruh sebesar $49,6 \%$ terhadap Earning Before Tax, sedangkan sisanya sebesar $50,4 \%$ dipengaruhi faktor lain.

Tabel 10. Hasil Uji Hipotesis Capital Adequacy Ratio Terhadap Earning Before Tax

\section{Cefficients}

d. Uji Hipotesis

Uji hipotesis Parsial (Uji t)

Pengujian hipotesis dengan uji $t$ digunakan untuk mengetahui hipotesis parsial mana yang diterima.

\begin{tabular}{|c|c|c|c|c|c|}
\hline \multirow[b]{2}{*}{ Model } & \multicolumn{2}{|c|}{ Unstandardized Coefficients } & \multirow{2}{*}{$\begin{array}{c}\text { Standardized Coefficients } \\
\text { Beta }\end{array}$} & & \multirow[b]{2}{*}{ Sig. } \\
\hline & $\mathrm{B}$ & Std. Error & & & \\
\hline 1 (Constant) & 57.268 & 43.447 & & 1.318 & .245 \\
\hline$C A R(X 1)$ & -1.320 & 2.539 & -.227 & -.520 & .625 \\
\hline
\end{tabular}

a. Dependent Variable: EBT (Y)

Berdasarkan hasil pengujian pada tabel di atas, diperoleh nilai $\mathrm{t}$ hitung $<$ t tabel atau $(-0,520<2,571)$, dengan demikian terdapat pengaruh

Tabel 11. Hasil Uji Hipotesis Loan to Deposit Ratio Terhadap Earning Before Tax

\section{Coefficients ${ }^{\mathrm{a}}$}

Unstandardized Coefficients Standardized Coefficients

\begin{tabular}{lr|rrrrr} 
Model & \multicolumn{1}{c}{ B } & Std. Error & Beta & \multicolumn{1}{c}{ t } & Sig. \\
\hline 1 (Constant) & 58.794 & 28.732 & & & 2.046 & .096 \\
\hline LDR $(X 2)$ & -.275 & .327 & & -.352 & -.841 & .439 \\
\hline
\end{tabular}

a. Dependent Variable: EBT (Y)

Berdasarkan hasil pengujian pada tabel di atas, diperoleh nilai $\mathrm{t}$ hitung $<\mathrm{t}$ tabel atau $-0,841>2,571$ ), dengan demikian terdapat pengaruh yang negatif signifikan atara Loan to yang negatif signifikan atara Capital Adequacy Ratio terhadap Earning Before Tax. memiliki kontribusi pengaruh sebesar memiliki kontribusi pengaruh sebesar $12,4 \%$ terhadap Earning Before Tax. 
Tabel 12. Hasil Uji Hipotesis Capital Adequacy Ratio dan Loan to Deposit Ratio Terhadap Earning Before Tax

ANOVA ${ }^{a}$

\begin{tabular}{lr|r|r|c|c} 
Model & Sum of Squares & df & Mean Square & F & Sig. \\
\hline 1 Regression & 89.105 & 2 & 44.552 & 1.970 & $.254^{\mathrm{b}}$ \\
\hline Residual & 90.475 & 4 & 22.619 & & \\
\hline Total & 179.579 & 6 & & & \\
\hline
\end{tabular}

Berdasarkan hasil pengujian pada tabel di atas, diperoleh nilai $\mathrm{F}$ hitung $<\mathrm{F}$ tabel atau $(1,970<5,410)$, dengan demikian terdapat pengaruh yang positif dan signifikan atara Capital Adequacy Ratio dan Loan to Deposit Ratio terhadap Earning Before Tax.

\section{PEMBAHASAN HASIL PENELITIAN}

\section{Pengaruh Capital Adequacy Ratio} Terhadap Earning Before Tax

Capital Adequacy Ratio berpengaruh signifikan terhadap Earning Before Tax dengan korelasi sebesar $-0,227$ atau memiliki hubungan yang negatif kuat dengan kontribusi pengaruh sebesar $5,1 \%$. Pengujian hipotesis diperoleh nilai t hitung $<\mathrm{t}$ tabel atau $(-0,520<2,571)$. Dengan demikian terdapat pengaruh negtif signifikan antara Capital Adequacy Ratio terhadap Earning Before Tax.

\section{Pengaruh Loan to Deposit Ratio Terhadap Earning Before Tax}

Loan to Deposit Ratio berpengaruh signifikan terhadap Earning Before Tax dengan korelasi sebesar $-0,352$ atau memiliki hubungan yang negatif kuat dengan kontribusi pengaruh sebesar $12,4 \%$. Pengujian hipotesis diperoleh nilai $\mathrm{t}$ hitung $<\mathrm{t}$ tabel atau $-0,841<2,571$ ). Dengan demikian terdapat pengaruh yang negatif signifikan antara Loan to Deposit Ratio terhadap Earning Before Tax.

\section{Pengaruh Capital Adequacy Ratio dan} Loan to Deposit Ratio Terhadap Earning Before Tax

Capital Adequacy Ratio dan Loan to Deposit Ratio berpengaruh signifikan terhadap Earning Before Tax dengan diperoleh persamaan regresi $Y=176,283$ 4,730X1 - 0,132X2, nilai korelasi sebesar 0,760 atau memiliki hubungan yang kuat dengan kontribusi pengaruh sebesar $49,6 \%$ sedangkan sisanya sebesar $50,4 \%$ dipengaruhi faktor lain. Pengujian hipotesis diperoleh nilai $\mathrm{F}$ hitung $<\mathrm{F}$ tabel atau $(1,970<5,410)$. Dengan demikian terdapat pengaruh yang negatif namun tidak antara Capital Adequacy Ratio dan Loan to Deposit Ratio terhadap Earning Before Tax.

\section{PENUTUP}

\section{Simpulan}

a. Capital Adequacy Ratio berpengaruh signifikan terhadap Earning Before Tax dengan kontribusi pengaruh sebesar $5,1 \%$. Uji hipotesis diperoleh nilai t hitung $<\mathrm{t}$ tabel atau $(-0,520<2,571)$.

b. Loan to Deposit Ratio berpengaruh signifikan terhadap Earning Before Tax dengan kontribusi pengaruh sebesar $12,4 \%$. Uji hipotesis diperoleh nilai $t$ hitung $<\mathrm{t}$ tabel atau $-0,841<2,571$ ).

c. Capital Adequacy Ratio dan Loan to Deposit Ratio berpengaruh signifikan terhadap Earning Before Tax dengan kontribusi pengaruh sebesar 49,6\% sedangkan sisanya sebesar 50,4\% dipengaruhi faktor lain. Uji hipotesis diperoleh nilai $\mathrm{F}$ hitung $<\mathrm{F}$ tabel atau $(1,970<5,410)$.

\section{Saran}

a. Disarankan untuk penelitian selanjutnya menggunakan periode tahun pengamatan yang lebih lama dan terbaru. Penambahan jumlah sampel penelitian dengan periode pengamatan yang lebih lama dan terbaru akan memberikan kemungkinan lebih besar dalam memperoleh hasil yang mendekati kondisi sesungguhnya.

b. Disarankan untuk menambah variabel independen dalam model penelitian atau mengganti variabel independen selain yang digunakan dalam penelitian, hal ini diharapkan mampu menunjukkan hasil yang lebih mendekati kondisi sesungguhnya atau hasil yang berbeda 
namun tetap mendekati kondisi sesungguhnya.

c. Disarankan untuk PT Bank BJB (Persero) Tbk, karena tidak terdapat pengaruh dari CAR, dan LDR terhadap EBT, maka PT. Bank BJB (Persero) Tbk, tidak perlu mengkhawatirkan akan dana kredit pihak ketiga dan modal yang dimiliki karena tidak mempengaruhi profit yang di dapatkan, akan tetapi sebaiknya PT. BJB (Persero) Tbk tetap memperhatikan variabel tersebut, dan memperhatikan variabel-variabel lainnya, seperti BOPO, NPL, NIM, ROA, EBIT, EAT dan lain sebagainya

\section{DAFTAR PUSTAKA}

Agus Harjito \& Martono, (2010) “Manajemen Keuangan" Yogyakarta: Penerbit Ekonisia.

Agus Sartono. (2010). "Manajemen Keuangan Toeri dan Aplikasi", Edisi keempat, Yogyakarta: Penerbit BPFE.

Algifari. (2015). "Analisis Regresi untuk Bisnis dan Ekonomi". Yogyakarta: BPFE.

Anjayani, NS., Lutfi, AM., Suhartono, A., Sari, WI., Sunarsi, D. (2020). Pengaruh Perputaran Persediaan dan Rasio Perputaran Aktiva Terhadap Return on Invesment Pada PT Gudang Garam Tbk. TIN: Terapan Informatika Nusantara. Vol. Issue 4 Pages 171-176

Antonio, Muhammad Syafi'I, "Bank Syariah Dari Teori Ke Praktek", Gema Insani Press, Jakarta, 2011.

Arikunto, Suharsimi (2014). "Prosedur Penelitian Suatu Pendekatan Praktek". Jakarta: Rineka Cipta.

Ascarya, "Akad dan Produk Bank Syariah", Rajawali Pers, Jakarta, 2011.

Ayyub Muhammad, "Understanding Islamic Finance", Gramedia Pustaka Utama, Jakarta, 2009.

Bambang Riyanto, (2011). "Dasar-dasar Pembelanjaan Perusahaan". Edisi ke empat, BPFE Yogyakarta.

Fahmi, Irham (2012), "Pengantar Manajemen Keuangan" Cetakan pertama. Bandung: Penerbit Alfabeta.

Gianni, Nur Gilang, "Faktor yang Mempengaruhi Earning Before Tax Mudharabah Pada Bank Umum Syariah
Di Indonesia", Unnes: Jurnal Ekonomi, 2013.

Harahap, Sofyan Syafri, "Teori Akuntansi edisi Revisi 2011”, Rajawali Pers, Jakarta, 2012.

Hasan Nurul Ichsan, M.A, "Perbankan Syariah (Sebuah Pengantar)", Referensi (GP Press Grup), Jakarta, 2014.

Imam Ghozali (2017). "Aplikasi Analisis Multivariate Dengan Program SPSS". Edisi Kelima. Semarang: Badan Penerbit Undip.

Istijanto (2014) "Riset Sumber Daya Manusia". Jakarta: PT. Gramedia Pustaka

Jasmani, J. (2018). Pengaruh Kinerja Keuangan Terhadap Harga Saham (Analisis Pada Perusahaan Property dan Real Estate Yang Go Public di Bursa Efek Indonesia. Jurnal Akuntansi Indonesia, 12(2).

Jasmani, J. (2019). The Effect of Liquidity and Working Capital Turnover on Profitability at PT. Sumber Cipta Multiniaga, South Jakarta. PINISI Discretion Review, 3(1), 29-38.

K Nufus, H Supratikta, A Muchtar, D Sunarsi. (2020). Analysis of Financial Performance: Case Study of PT. X Employee Cooperative. Utopía Y Praxis Latinoamericana. Vol. 25. Pages 429444

Kasmir (2010), “Analisis Laporan keuangan”, penerbit raja grafindo persada, Jakarta

Kasmir, (2010). "Pengantar Manajemen Keuangan", Edisi Pertama, Cetakan kedua, Jakarta: Penerbit Prenada Media.

Kasmir. (2012) "Pengantar Manajemen Keuangan", Edisi Pertama, Cetakan kedua, Jakarta: Prenada Media.

Martono dan Agus Harjito, (2011). "Manajemen Keuangan", Jakarta: Penerbit Ekonisia..

Munawir (2010), "Analisis Laporan Keuangan", Edisi Ke Empat, Penerbit Liberty, Yogyakarta.

Santoso, Singgih (2015). "Menguasai Statistik Multivariat". Jakarta: PT Elex Media Komputindo.

Sartono, "Manajemen Keuangan Aplikasi Dan Teori", Edisi Keempat, BPFE, Yogyakarta, 2008. 
Sarwani, S., Akbar, I. R. ., Handoko, A. L. ., \& Ilham, D. . (2020). Pengaruh Pelatihan dan Motivasi terhadap Produktivitas Kerja Karyawan pada PT. Lion Mentari Airlines Bandara Internasional Soekarno Hatta Cengkareng. Jurnal Ilmu Komputer Dan Bisnis, 11(2a), 91100.https://doi.org/10.47927/jikb.v1 $1 \mathrm{i} 2 \mathrm{a} .24$

Sawir, (2003). “Analisis Kinerja Keuangan dan Perencanaan Keuangan Perusahaan", Cetakan ketiga, Jakarta: Penerbit PT. Gramedia Pustaka Utama.

Sugiyarso, G. dan F. Winarni, "Manajemen Keuangan (Pemahaman Laporan Keuangan, Pengelolaan Aktiva, Kewajiban dan Modal serta Pengukuran
Sugiyono (2017), "Metode Penelitian Administrasi : dilengkapi dengan Metode R \& D”. Bandung: Alfabeta.

Suhartono, A., Jati, W., \& Sunarsi, D. (2019). Pengaruh Earning Per Share Dan Return On Asset Terhadap Harga Saham Pada PT. Bank Negara Indonesia Tbk Periode 2009-2018. Jurnal Manajemen, Bisnis dan Organisasi (JUMBO), 3(3), 182-194.

Yonata, H. . ., Setiawan, P., Santamoko, R. ., Ilham, D. ., \& Asdiany, D. . (2020). Pengaruh Kualitas Pelayanan dan Kepuasan Konsumen terhadap Loyalitas Pelanggan pada PT. Satria Antaran Prima. Jurnal Ilmu Komputer Dan Bisnis, 11(2), 2502-2514. https://doi.org/10.47927/jikb.v11i2.1 4 